U.S. DEPARTMENT OF THE INTERIOR

U.S. GEOLOGICAL SURVEY

Prepared in cooperation with the

GRAND CANYON MONITORING AND RESEARCH CENTER

A Stage-Normalized Function for the

Synthesis of Stage-Discharge

Relations for the Colorado River

in Grand Canyon, Arizona 


\section{A Stage-Normalized Function for the Synthesis of Stage-Discharge Relations for the Colorado River in Grand Canyon, Arizona}

Water-Resources Investigations Report 03-4037

Prepared in cooperation with the

GRAND CANYON MONITORING AND RESEARCH CENTER 


\section{U.S. DEPARTMENT OF THE INTERIOR \\ GALE A. NORTON, Secretary}

U.S. GEOLOGICAL SURVEY

Charles G. Groat, Director

The use of firm, trade, and brand names in this report is for identification purposes only and does not constitute endorsement by the U.S. Geological Survey.

For additional information write to:

District Chief

U.S. Geological Survey

Water Resources Division

520 N. Park Avenue, Suite 221

Tucson, AZ 85719-5035
Copies of this report can be purchased from:

U.S. Geological Survey

Information Services

Box 25286

Federal Center

Denver, C0 80225-0046

Information about U.S. Geological Survey programs in Arizona is available online at http://az.water.usgs.gov. 


\section{CONTENTS}

Abstract

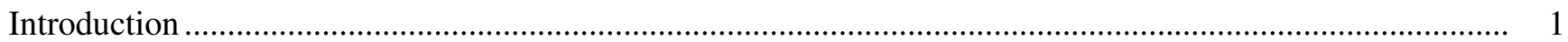

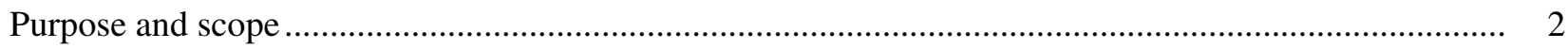

Study area

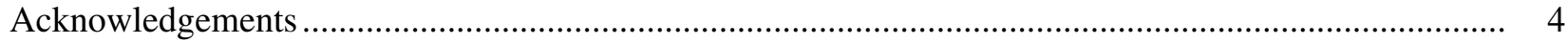

Development of a stage-normalized function for the synthesis of stage-discharge relations ........................... 4

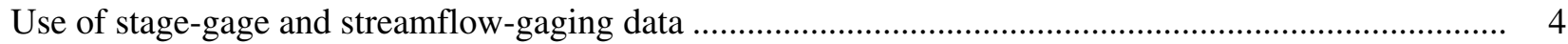

Similarity of stage-discharge relations at temporary stage gages .................................................... 4

Formulation of stage-discharge relations using stage-normalized curves ............................................ 4

Comparisons of stage-normalized curve method results with data and stars model results ............................. 5

Comparison with stage-gage and streamflow-gaging station data...................................................... 5

Comparison with STARS model results and NAU stage measurements............................................. 8

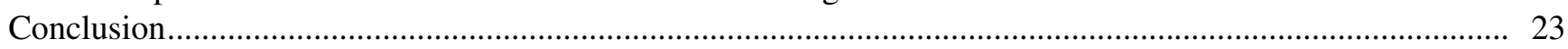

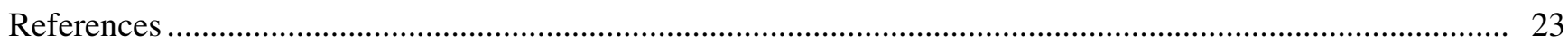




\section{FIGURES}

1. Map showing study area and location of temporary stage-gaging stations and continuous-record streamflow-gaging stations, Colorado River, Lees Ferry to Phantom Ranch.

2-8. Graphs showing:

2. Stage-discharge relations calculated from the stage-normalized curve, the onedimensional flow model and stage records, and the reach-averaged relation from which the stage-normalized curve is derived

3. Root-mean-square error and maximum absolute error of stage predicted from discharges between 240 and 1,270 cubic meters per second as a function of the difference in discharge of the stage-discharge pairs used to restore dimension to the stage-normalized curve.

4. Stage-discharge relations from the stage-normalized curve, stage-discharge relation constructed from discharge measurements at the streamflowgaging stations, and the reach-averaged relation from which the stagenormalized curve is derived

5. Root-mean-square error and maximum absolute error of stage predicted from discharges between 240 and 1,270 cubic meters per second as a function of the difference in discharge of the stage-discharge pairs used to restore dimension to the stage-normalized curve.

6. Rating curve formulated for the Colorado River above the Little Colorado River streamflow-gaging station and discharge measurements used in the formulation of the rating curve

7. Comparisons of the Northern Arizona University (NAU) stage measurements at known discharges with Stream Tube model for Alluvial River Simulation (STARS) predictions and rating curves constructed with the stage-normalized curve (SNC)

8. Root-mean-square (RMS) error of the stage predicted by the stage-normalized curve (SNC) method and by the Stream Tube model for Alluvial River Simulation (STARS) model

\section{CONVERSION FACTORS AND DATUMS}

\begin{tabular}{lcl}
\hline Multiply & \multicolumn{1}{c}{ By } & To obtain \\
\hline meter $(\mathrm{m})$ & 3.281 & foot \\
kilometer $(\mathrm{km})$ & 0.6214 & mile \\
cubic meter per second $\left(\mathrm{m}^{3} / \mathrm{s}\right)$ & 35.31 & cubic foot per second \\
cubic meter per second $\left(\mathrm{m}^{3} / \mathrm{s}\right)$ & 70.07 & acre-foot per day \\
cubic meter per second $\left(\mathrm{m}^{3} / \mathrm{s}\right)$ & 22.83 & million gallons per day \\
\hline
\end{tabular}




\title{
A Stage-Normalized Function for the Synthesis of Stage-Discharge Relations for the Colorado River in Grand Canyon, Arizona
}

\author{
By Stephen M. Wiele and Margaret Torizzo
}

\section{Abstract}

A method was developed to construct stage-discharge rating curves for the Colorado River in Grand Canyon, Arizona, using two stage-discharge pairs and a stage-normalized rating curve. Stage-discharge rating curves formulated with the stage-normalized curve method are compared to (1) stage-discharge rating curves for six temporary stage gages and two streamflow-gaging stations developed by combining stage records with modeled unsteady flow; (2) stage-discharge rating curves developed from stage records and discharge measurements at three streamflow-gaging stations; and (3) stages surveyed at known discharges at the Northern Arizona Sand Bar Studies sites. The stagenormalized curve method shows good agreement with field data when the discharges used in the construction of the rating curves are at least 200 cubic meters per second apart. Predictions of stage using the stage-normalized curve method are also compared to predictions of stage from a steadyflow model.

\section{INTRODUCTION}

Since the closure of Glen Canyon Dam in 1963, flow in the Colorado River through Grand Canyon has been dominated by the discharge released through the dam. Because the flow through the dam is used to generate power, the dam releases have typically followed a diurnal variation, which in the past has varied by as much as an order of magnitude in less than a day. Large variations in discharge over short periods of time can also be produced by the release of flows in excess of the dam's powerplant capacity that may be used to restore sand deposits and habitat, a strategy endorsed by an Environmental Impact Statement (EIS; U.S. Department of the Interior, 1995). This method of restoring the river corridor environment using high flows was tested in 1996 with a release of $1,273 \mathrm{~m}^{3} / \mathrm{s}$ for 7 days.
The daily variations in discharge and the prospect of sudden large increases in discharge for environmental reasons have generated keen interest in a capability to predict river stage at particular locations. Stage ranges and inundation levels are important for their potential effect on native and non-native fish, erosion and restoration of sandbars, and the exposure of archeological artifacts by erosion and the efforts to preserve them. In addition, stage ranges are of interest to visitors to Grand Canyon National Park who camp near river level. The method for constructing local stage-discharge relations presented in this report was part of a study conducted in cooperation with the Grand Canyon Monitoring and Research Center (GCMRC) Socio-Cultural Resources Program.

Current methods for predicting stage as a function of discharge consist of stage-discharge rating curves formulated by the Northern Arizona University (NAU) Sand Bar Studies (Joseph Hazel, Northern Arizona 
University, written commun., 1999) and an implementation of the Stream Tube model for Alluvial River Simulation (STARS) by Randle and Pemberton (1987). The NAU rating curves are derived from numerous surveys of water-surface elevation at known discharges and are available for the 14 NAU beach survey sites in the length of river considered in this study. The STARS model is a steady-flow onedimensional model that predicts stage at any location. Surveys of channel shape used in the model consist of 199 cross sections measured by Wilson (1986). The remaining cross sections used in the model, including the critical cross sections that define hydraulic controls, were estimated from the river width and the channel shape above the water surface visible in aerial photos. The estimation of channel shape was required by the sparseness of the available bathymetric data and is a potential source of error in the prediction of stage.

An unsteady, reach-averaged one-dimensional model (Wiele and Griffin, 1997) has been shown to predict accurately the downstream translation and evolution of discharge waves released from Glen Canyon Dam. This model, however, predicts stage in a reachaveraged sense only. It was not designed to predict local stage accurately.

The method of formulating stage-discharge relations presented in this report requires only the difference in stage at two known discharges. This information could be obtained by workers at a particular site observing high and low stages and determining discharges from rating curves for nearby streamflowgaging stations, if present, or by routing flow with the one-dimensional model of unsteady flow (Wiele and Griffin, 1997; Korman and others, 2000). Temporary stage gages, such as those installed by Gauger (1997), would provide the necessary information if the flows were fluctuating over a sufficient range. The stagenormalized curve used in the formulation of the stagedischarge relations was derived from data in the study area, and its application should be confined to the study area. The method also depends on the observation that stage-discharge relations in the study area tend to have a similar shape, an observation that may not hold true elsewhere. The method in this report would work well with proposed efforts by the GCMRC (Mike Liszewski and Steve Mietz, GCMRC, Information Technology Resources, oral commun., 2002) to obtain river stages downstream from Glen Canyon Dam using aerial photos that would be taken during steady flows of $225 \mathrm{~m}^{3} / \mathrm{s}$ and $1,273 \mathrm{~m}^{3} / \mathrm{s}$.

\section{Purpose and Scope}

This report presents an empirically based method of formulating stage-discharge relations at discrete locations with minimum data. The method uses the difference in stage at two known discharges and a general curve that relates a nondimensional stage to discharge to formulate stage-discharge rating curves. Stage-discharge rating curves formulated with the stage-normalized curve (SNC) method are compared to stage-discharge rating curves for six temporary stage gages and two streamflow-gaging stations developed by combining stage records with modeled unsteady flow, stage-discharge rating curves developed from stage records and discharge measurements at three streamflow-gaging stations, and the NAU rating curves. Stage predictions using the SNC method are also compared to predictions of the STARS model at the NAU study sites.

\section{Study Area}

Locations on the Colorado River through Grand Canyon are traditionally defined by the river mile downstream from Lees Ferry (river mile 0). Although we use metric units for describing our methods and results, we adhere to the use of river miles to specify study site locations. The river miles used in this report were taken from a popular river guide in widespread use (Stevens, 1990).

The material in this report was part of a larger study concerned with the effects of the operation of Glen Canyon Dam on cultural resources in Grand Canyon. Most of the study was concerned with a section of the river that contains abundant artifacts that have become exposed and damaged by erosion located about 105 to $116 \mathrm{~km}$ below Lees Ferry. The study area (fig. 1) was expanded to include 3 streamflow-gaging stations, 6 temporary gaging stations, and 10 NAU survey sites between river mile -6 (6 miles upstream from Lees Ferry) and Grand Canyon (river mile 87). 

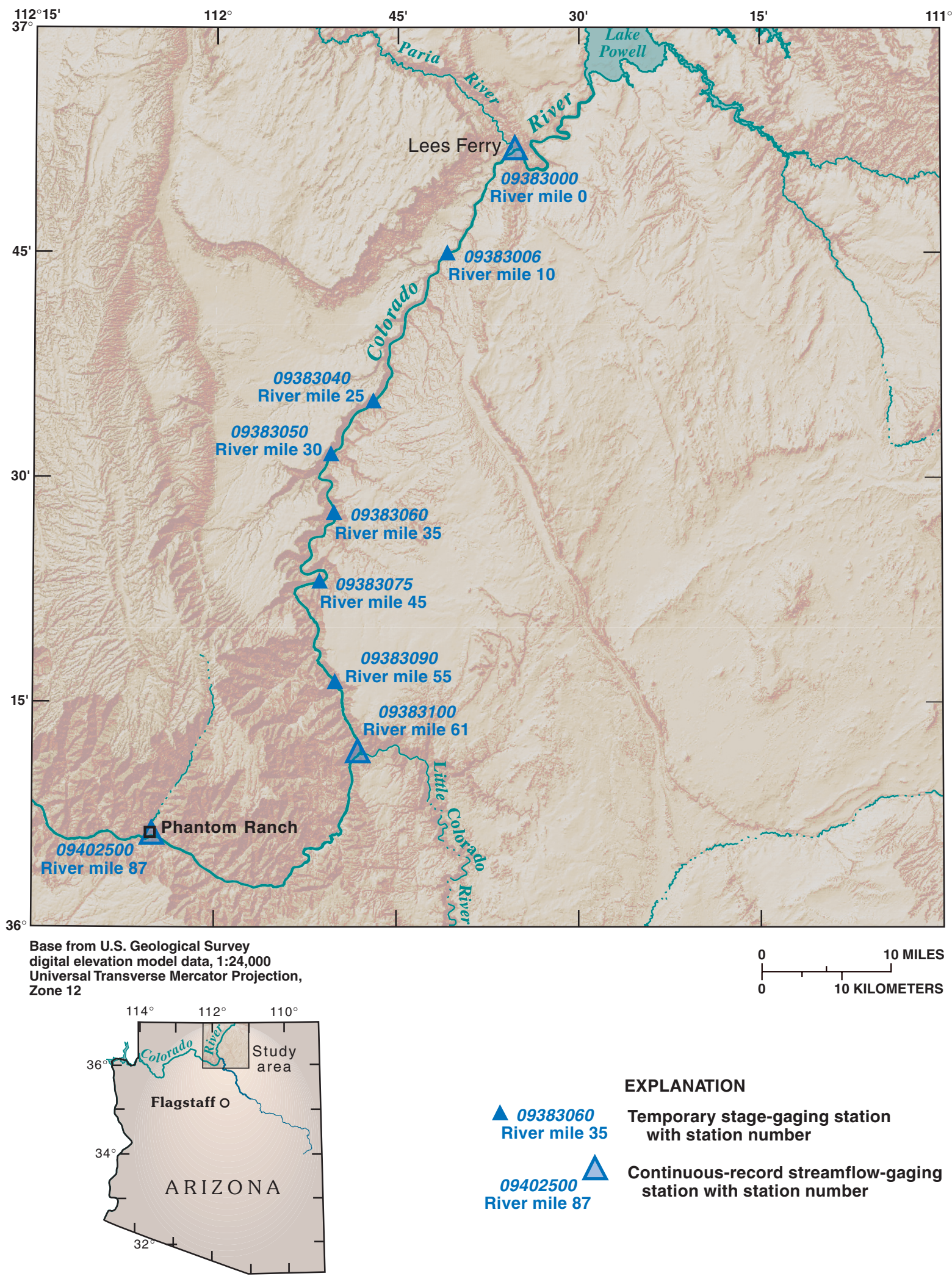

\section{EXPLANATION}

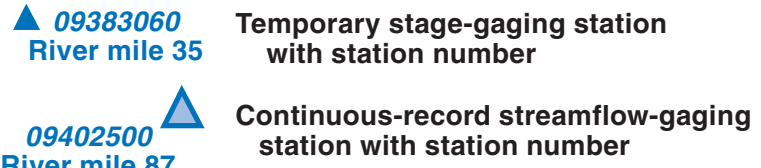

Figure 1. Study area and location of temporary stage-gaging stations and continuous-record streamflow-gaging stations, Colorado River, Lees Ferry to Phantom Ranch. 


\section{Acknowledgements}

We thank Ruth Lambert, Socio-Cultural Resources Program Manager at the Grand Canyon Monitoring and Research Center, for her support of this project. We also thank Joe Hazel, Matt Kaplinski, and Mark Manone, Northern Arizona University Sand Bar Studies, for providing stage-discharge data for their survey sites.

\section{DEVELOPMENT OF A STAGE-NORMALIZED FUNCTION FOR THE SYNTHESIS OF STAGE- DISCHARGE RELATIONS}

\section{Use of Stage-Gage and Streamflow-Gaging Data}

Stage data were available from temporary stage gages that were installed at approximately $8-\mathrm{km}$ intervals in the 388-km reach between Glen Canyon Dam and Diamond Creek (Gauger, 1997). The gages were operated between 1990 and 1994, and a subset was reactivated during an experimental release of $1,273 \mathrm{~m}^{3} / \mathrm{s}$ in 1996 . The six temporary gaging stations in the study area that were operational during the 1996 experimental release were used in this study. Stage was initially recorded at 15-minute intervals. In 1991-92, a new type of temporary stage gage was installed that recorded at 5-minute intervals. Discharges were not measured at the temporary stage-gage sites, so stagedischarge relations could not be formulated using traditional USGS methods (Rantz and others, 1982a, b). In addition to the temporary stage gages, permanent streamflow-gaging stations were located at Lees Ferry (river mile 0; station number 09380000), above the confluence with the Little Colorado River (river mile 62; 09381000), and at Grand Canyon (river mile 87; 09402500).

\section{Similarity of Stage-Discharge Relations at Temporary Stage Gages}

Examination of stage records from the temporary stage gages revealed significant variability in the difference in stages for the same difference in discharge (Griffin and Wiele, 1997). Even in reaches regarded as having similar morphology on the basis of bedrock type near river level (Schmidt and Graf, 1990), the same change in discharge at two gage sites typically produced significant differences in the change in stage at those sites. Griffin and Wiele (1997), however, found that if the stages were normalized by dividing by the difference in stage at the two discharges, the stagedischarge relations followed a similar curve.

The shape of the stage-normalized curve is a function of channel shape and total roughness. In many rivers, stage-discharge relations can be estimated over a range of discharges by using the channel shape and reasonable approximations of channel roughness, such as those represented by the roughness length $\mathrm{z}_{0}$ (Keulegan, 1938) or Manning's n. Wiele and Smith (1996) demonstrated that the reach-averaged stagedischarge relations in the Colorado River in Grand Canyon vary significantly from those predicted by constant roughness parameters. The channel friction decreases as the discharge increases at a much faster rate than predicted by constant roughness parameters.

The empirically derived, stage-normalized stagedischarge relation provides a general curve that can be applied to specific sites by redimensionalizing the stage with appropriate data. The only information required to restore dimension to the normalized stage is the difference in stage at two known discharges.

\section{Formulation of Stage-Discharge Relations Using Stage-Normalized Curves}

The hydraulic geometry for the Colorado River in Grand Canyon developed by Wiele and Griffin (1997) was used to represent a general stage-normalized stagedischarge rating curve. This hydraulic geometry was derived from streamflow-gaging station records at Lees Ferry and Diamond Creek, $362 \mathrm{~km}$ downstream from Lees Ferry, during the declining limb of the 1996 experimental release. During the declining limb, the discharge was reduced from about $1,273 \mathrm{~m}^{3} / \mathrm{s}$ to $226 \mathrm{~m}^{3} / \mathrm{s}$ over 45 hours. Wiele and Griffin (1997) argued that because the discharge declined slowly at a nearly steady rate, the wave speed between the two streamflow-gaging stations was accurately represented by the kinematic wave speed, $d Q / d A$, where $Q$ is discharge and $A$ is cross-sectional area. They fit a 
function to the wave speed between the two streamflow-gaging stations as a function of discharge and integrated it to derive a relation between $Q$ and $A$, using results from a dye study (Graf, 1995) to supply the constant of integration. Comparisons of predictions by the original one-dimensional unsteady flow model (Wiele and Smith, 1996) updated with the new hydraulic geometry (Wiele and Griffin, 1997) to streamflow-gaging station data demonstrated the accuracy of the hydraulic geometry derived from streamflow-gaging stations. The reach-averaged relation between $Q$ and stage was completed with a relation between stage and $A$ determined from average channel shape. Normalizing the reach-averaged relation between stage and discharge by dividing by the difference in stage at 1,273 and $226 \mathrm{~m}^{3} / \mathrm{s}$ discharges produces this general stage-normalized stage-discharge relation:

$$
\begin{aligned}
& z^{*}=-0.2686+1.377 \times 10^{-3} Q- \\
& 3.5917 \times 10^{-7} Q^{2}+4.9906 \times 10^{-11} Q^{3}
\end{aligned}
$$

where $z$ is stage in meters, the superscript $*$ denotes non dimensional stage, and $Q$ is discharge in cubic meters per second. To formulate a stage-discharge relation at a particular site, the nondimensional stage is scaled by the difference in stage at two known discharges with:

$$
z(Q)=z_{\text {qlow }}+\left(z^{*}(Q)-z_{\text {qlow }}^{*}\right)\left(\frac{z_{\text {qhigh }}-z_{\text {qlow }}}{z_{\text {qhigh }}^{*}-z_{\text {qlow }}^{*}}\right),
$$

where the subscript qhigh denotes stage at the higher discharge of the discharge pair, and qlow denotes stage at the lower discharge of the discharge pair.

\section{COMPARISONS OF STAGE-NORMALIZED CURVE METHOD RESULTS WITH DATA AND STARS MODEL RESULTS}

Stage-discharge relations predicted with the SNC method were compared to stage-discharge relations derived from field measurements to assess the accuracy of the SNC method. Stage-discharge relations predicted with the SNC method were also compared to stage-discharge relations predicted with the STARS model to assess the relative accuracies of the two methods.

\section{Comparison with Stage-Gage and Streamflow- Gaging Station Data}

In addition to the SNC method, the discussion in this section refers to stage-discharge relations that were developed using two other methods. These additional two stage-discharge relations are used to evaluate the accuracy of results obtained with the SNC method.

1. Stage-discharge relations were constructed at six temporary stage gages by routing the discharge from Lees Ferry with the onedimensional unsteady flow model (Wiele and Griffin, 1997) to determine the discharge that corresponds to the measured stage. Stagedischarge relations were constructed by routing the receding limb of the 1996 experimental release from Lees Ferry and combining the stage record from the gage with the discharge predicted by the model at that site. This yields a rating curve ranging from about $240 \mathrm{~m}^{3} / \mathrm{s}$ to about $1,250 \mathrm{~m}^{3} / \mathrm{s}$.

2. Stage-discharge relations have been developed by the USGS from discharge and stage measured at three USGS streamflow-gaging stations.

Method 1 makes use of the best data available but is not a completely independent test of the SNC method. The model used to route the wave downstream in the construction of the local stage-discharge relations uses the same stage-discharge relation (method 1) that is nondimensionalized for use in the local rating curve reconstruction with the SNC method. The three stage gages with rating curves developed from discharge measurements provide a more independent test of the SNC method.

The rating curves determined from the onedimensional routing model and the stage records are compared to the stage-discharge relations calculated with the stage-normalized curve in figure 2. 


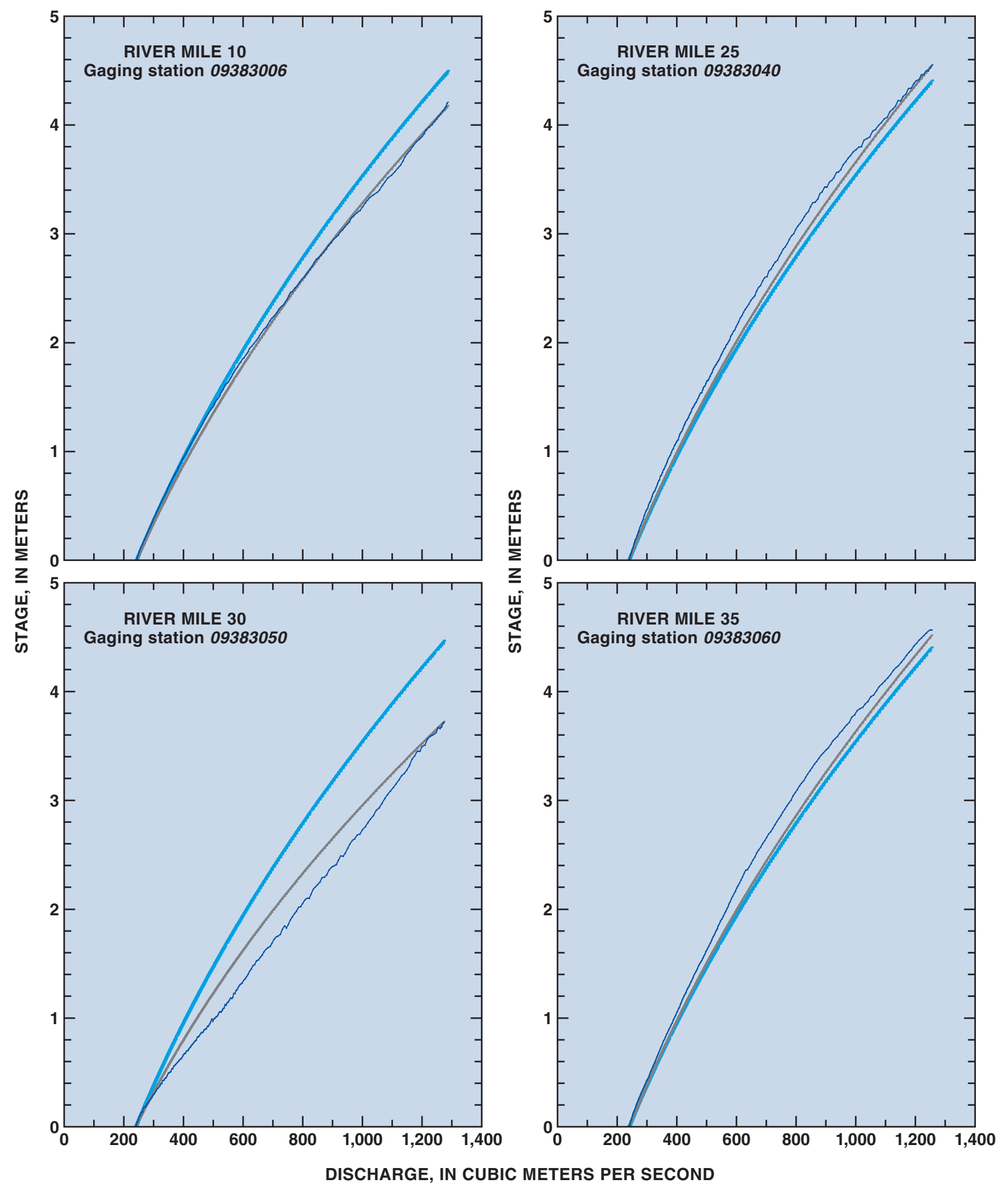

Figure 2. Stage-discharge relations calculated from the stage-normalized curve, the one-dimensional flow model and stage records, and the reach-averaged relation from which the stage-normalized curve is derived. 

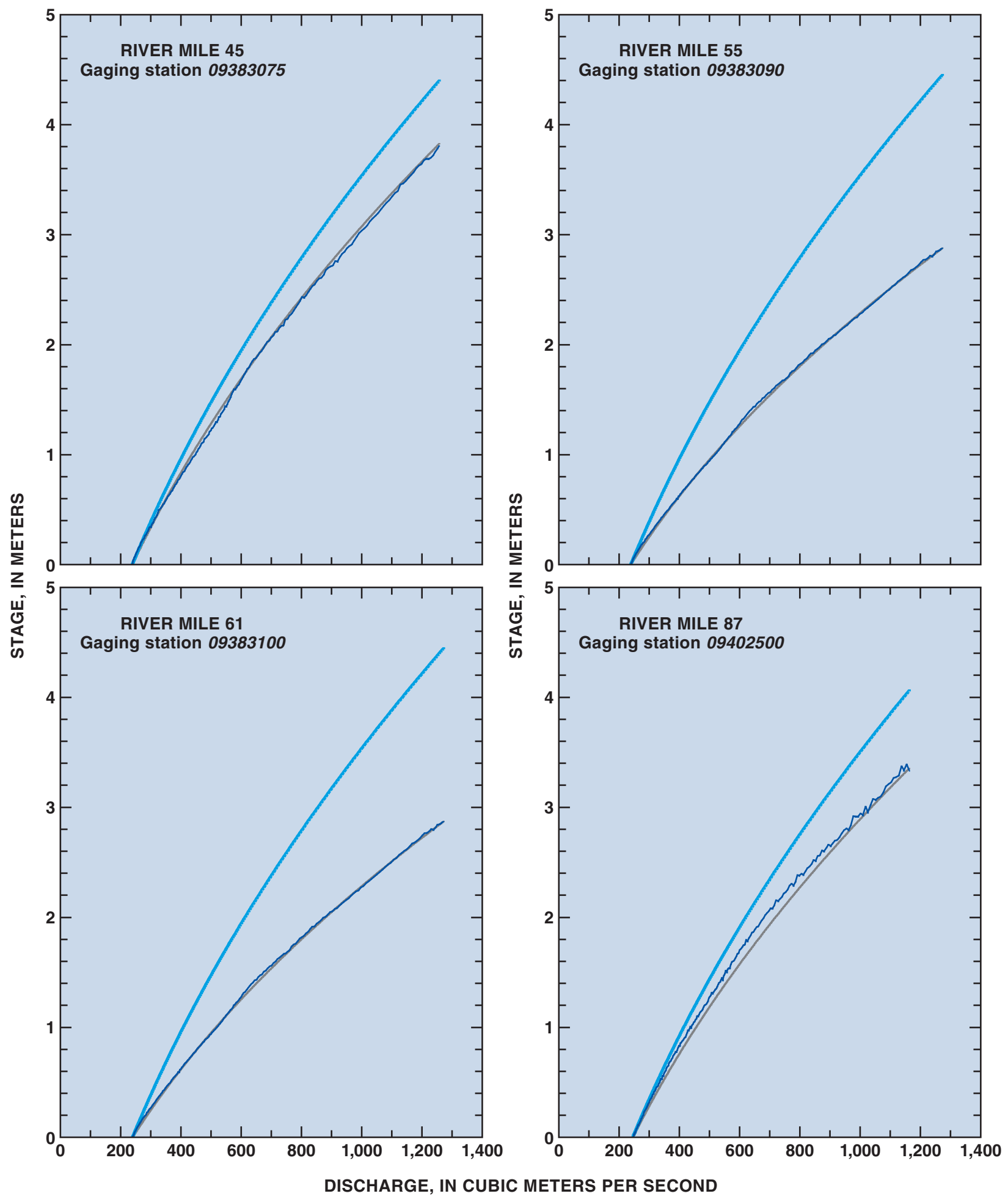

EXPLANATION

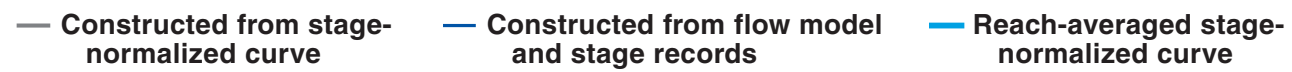

Figure 2. Continued. 
The stage-discharge relation from the hydraulic geometry used in the one-dimensional model from which the stage-normalized curve is derived is also shown for reference. In these figures, the stagedischarge pairs were chosen from the highest and lowest discharges shown. The accuracy of the SNC method depends on the difference between the stagedischarge pairs used to restore dimension to the stagenormalized curve, and the accuracy generally increases as the difference increases. Figure 3 shows the differences between the rating curves determined with the SNC method and method 1 as a function of the difference between the discharge in the stage-discharge pairs used to restore the stage dimension in the SNC method. The root-mean-square error of the SNC method was calculated relative to method 1 using about 400 points for each value represented in the plots. The lowest value in the stage-discharge pairs is the same for each gage, about $240 \mathrm{~m}^{3} / \mathrm{s}$. For small differences in discharge pairs (less than about $200 \mathrm{~m}^{3} / \mathrm{s}$ ) the root-mean-square errors are large, but in most cases the error is reasonably small for differences greater than about $200 \mathrm{~m}^{3} / \mathrm{s}$. Seven of eight gages (the Lees Ferry gage is not included here because it was used as input to the one-dimensional model) show good agreement. The gage that shows poorer agreement is the temporary gage at river mile 30, which has an unusual relation between discharge and stage. At river mile 30, the apparent rating curve from the model and gage records is nearly a straight line.

At the three streamflow-gaging stations, rating curves have been developed by the USGS Flagstaff office on the basis of discharge measurements (method 2). Comparisons of these rating curves with those developed with the SNC method are similar to the comparisons of method 1 and the SNC method: excellent agreement at Lees Ferry (despite a relatively low range in stage over the same range of discharge as at the other gages), poorer agreement at the LCR gage, and intermediate agreement at the Grand Canyon gage (figs. 4 and 5). The rating curve at the above LCR gage, along with the temporary stage gage at river mile 30 , has a shape that is dissimilar to that of curves at the other gages examined in this study. In this case, the rating curve has a sigmoidal shape. This shape may be a result of the local hydraulics, but could also result from the relative sparsity of discharge measurements above the powerplant capacity of about $900 \mathrm{~m}^{3} / \mathrm{s}$ (fig. 6).

\section{Comparison with STARS Model Results and NAU Stage Measurements}

The release of a Graphical User Interface (Korman and others, 2000) provides ready access to the onedimensional unsteady flow model (Wiele and Smith, 1996; Wiele and Griffin, 1997) and stage predictions from the STARS model (Randle and Pemberton, 1987). Results from both methods were compared to the rating curves by the Northern Arizona University Sand Bar Studies (Joseph Hazel, Northern Arizona Uuniversity, written commun., 2000) on the basis of NAU's stage measurements at discharges estimated from streamflow-gaging stations. For the comparisons, STARS predictions of stage at the NAU study sites were plotted along with the NAU measured stages (fig. 7). In addition, a family of rating curves constructed with the SNC method were plotted in which each solid line represents a rating curve corresponding to different ranges in the stage-discharge pairs used in the construction of the rating curve. For consistency and ease of representation in the plot, the lower stage used in the SNC method is the lowest stage measured by NAU. Higher stages measured by NAU and the corresponding discharges were used to complete the stage-discharge pair necessary for the construction of the rating curve. Some stages measured by NAU were omitted for clarity, especially if there was more than one value within a narrow stage range. The root-mean-square errors for each rating curve shown in figure 7 and for the STARS model are shown in figure 8.

Stage-discharge relations derived from application of the STARS model show good agreement with the NAU data set at 10 of the 14 sites. Relations constructed with the SNC method consistently show agreement with the NAU data in all cases that is as good as or better than the agreement of the STARS predictions with the NAU data if the difference in discharge used in the SNC method exceeds about $200 \mathrm{~m}^{3} / \mathrm{s}$. With differences in discharge of only about $100 \mathrm{~m}^{3} / \mathrm{s}$, the results are generally reasonable but can be inconsistent. With very small differences (less than about $50 \mathrm{~m}^{3} / \mathrm{s}$ ) in discharge, stage-discharge relations constructed with the SNC method tend to show poor agreement with the NAU measurements. 


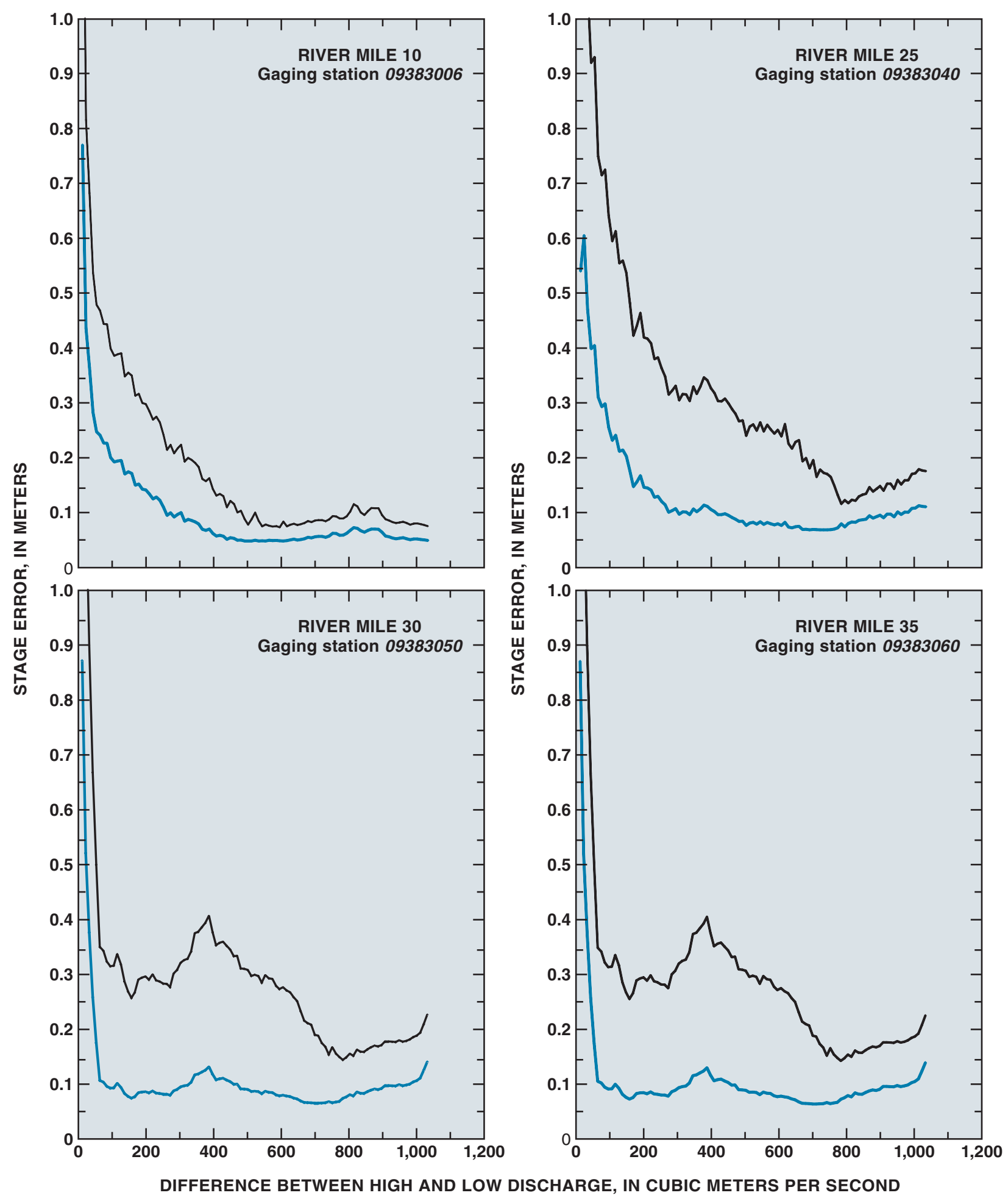

Figure 3. Root-mean-square error and maximum absolute error of stage predicted from discharges between 240 and 1,270 cubic meters per second as a function of the difference in discharge of the stage-discharge pairs used to restore dimension to the stage-normalized curve. In these graphs, the rating curve determined from the one-dimensional flow model and stage records is used as a reference in the error calculations. 

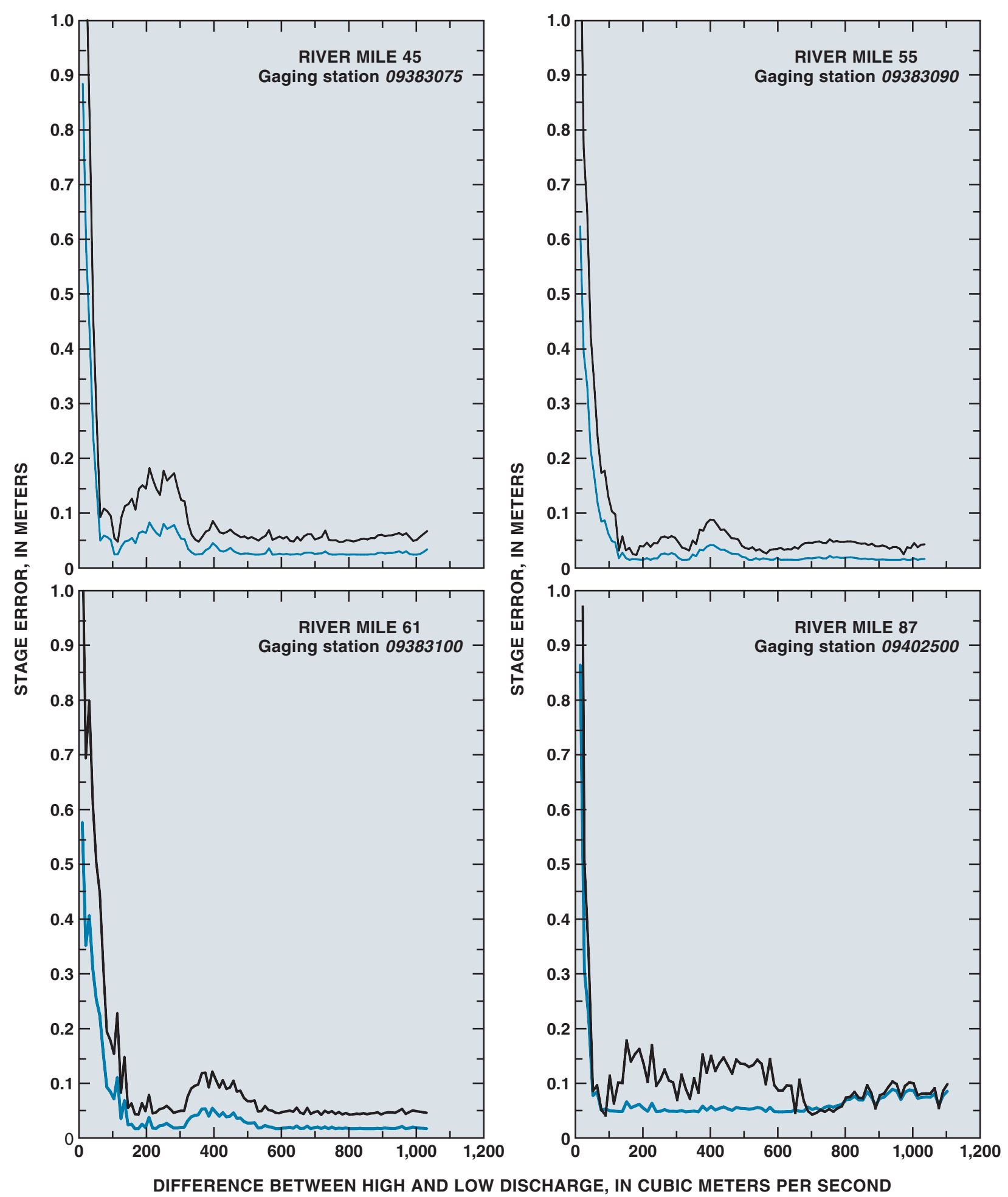

EXPLANATION

Root-mean-square $\quad$ Maximum error
error

Figure 3. Continued. 

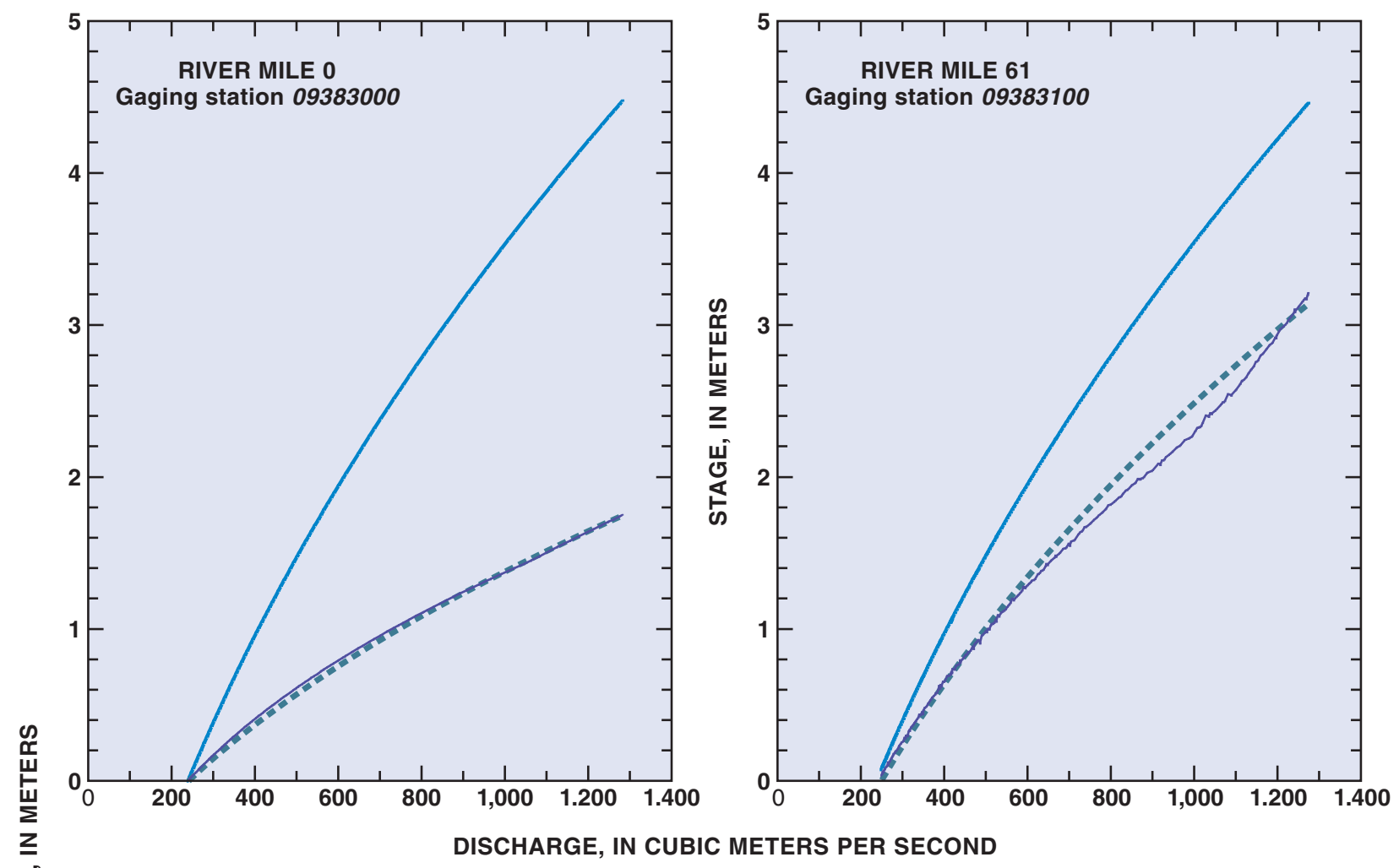

峁

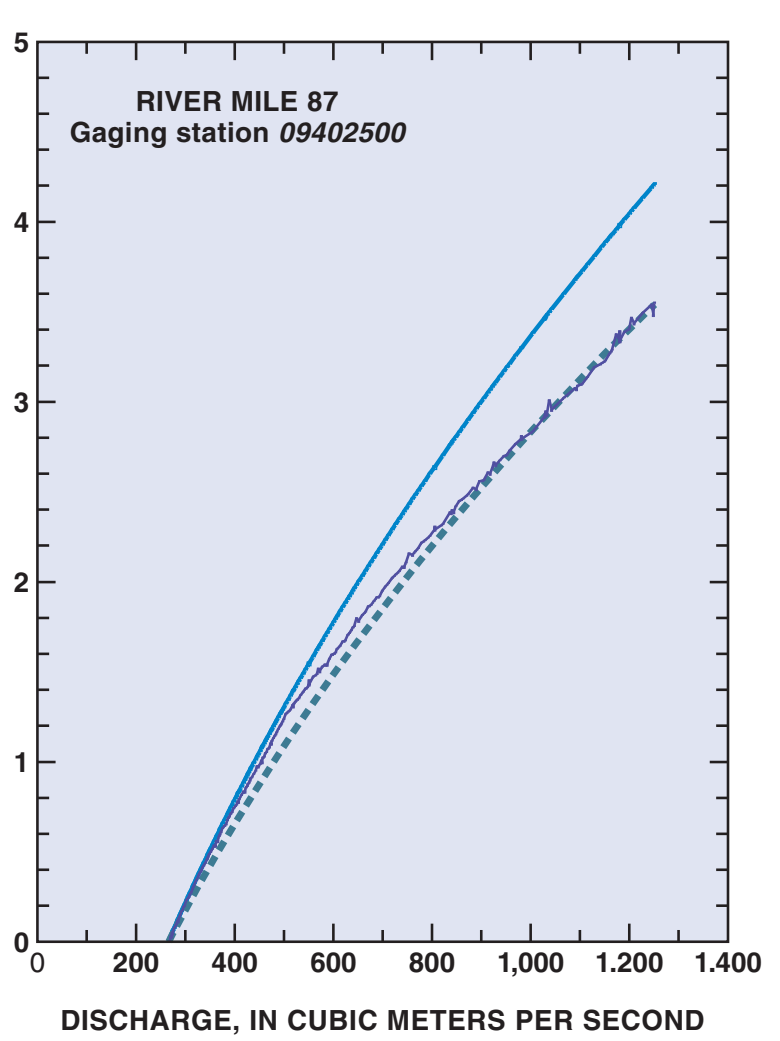

\section{EXPLANATION}

- - Constructed from stagenormalized curve

- Constructed from gage record

- Reach-averaged curve

Figure 4. Stage-discharge relations from the stage-normalized curve, stage-discharge relation constructed from discharge measurements at the streamflow-gaging stations, and the reach-averaged relation from which the stage-normalized curve is derived. 

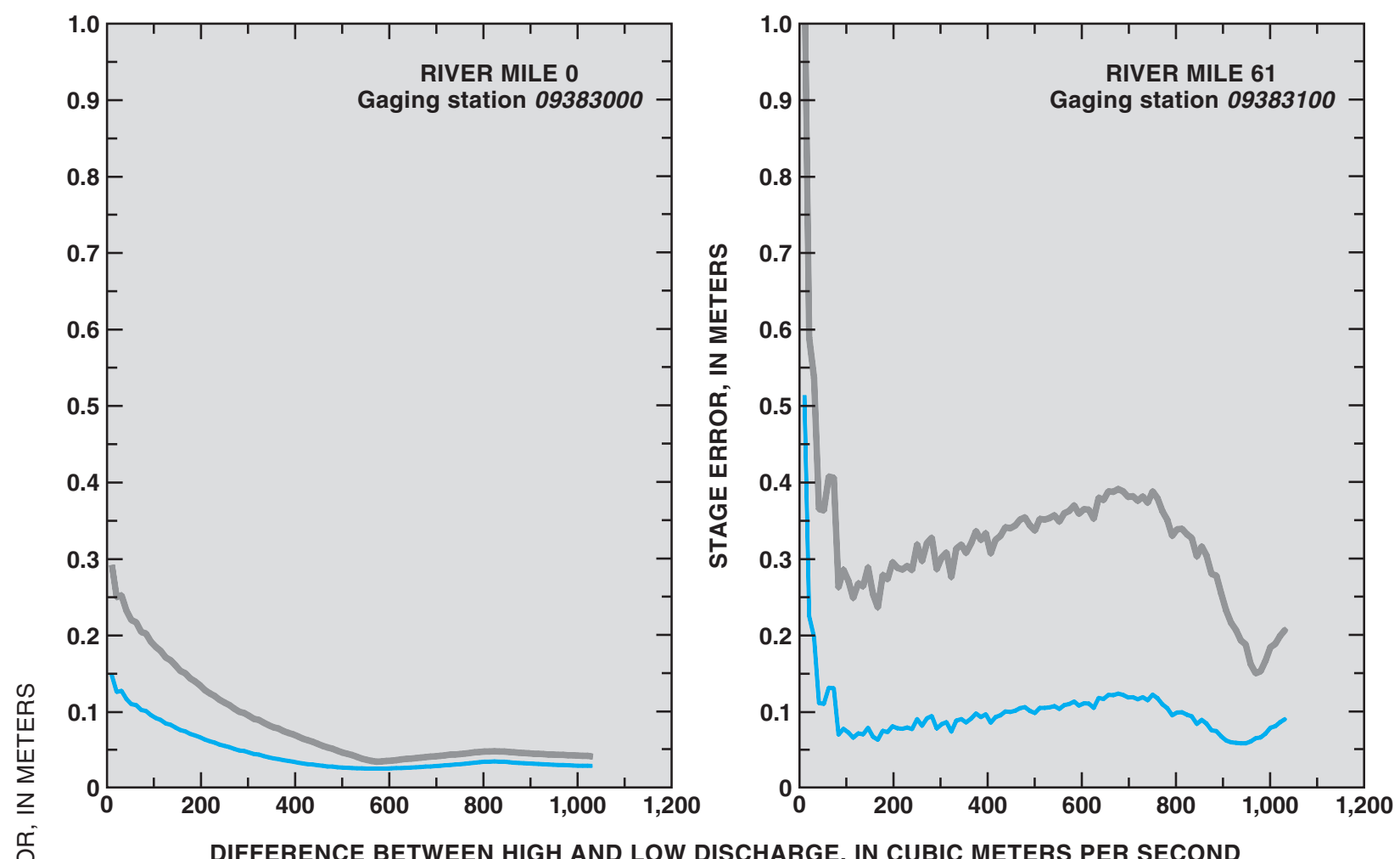

㟧

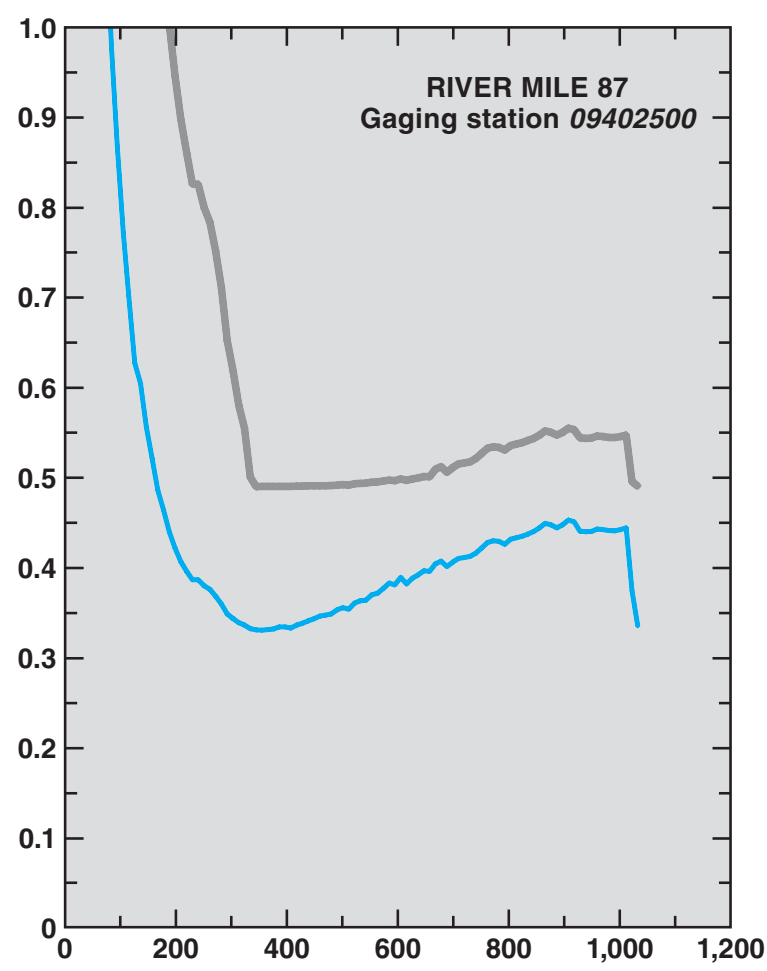

EXPLANATION

- Root-mean-square

curve

- Maximum error

DIFFERENCE BETWEEN HIGH AND LOW DISCHARGE, IN CUBIC METERS PER SECOND

Figure 5. Root-mean-square error and maximum absolute error of stage predicted from discharges between 240 and 1,270 cubic meters per second as a function of the difference in discharge of the stage-discharge pairs used to restore dimension to the stagenormalized curve. In these graphs, the rating curve determined from discharge measurements is used as a reference in the error calculations. 


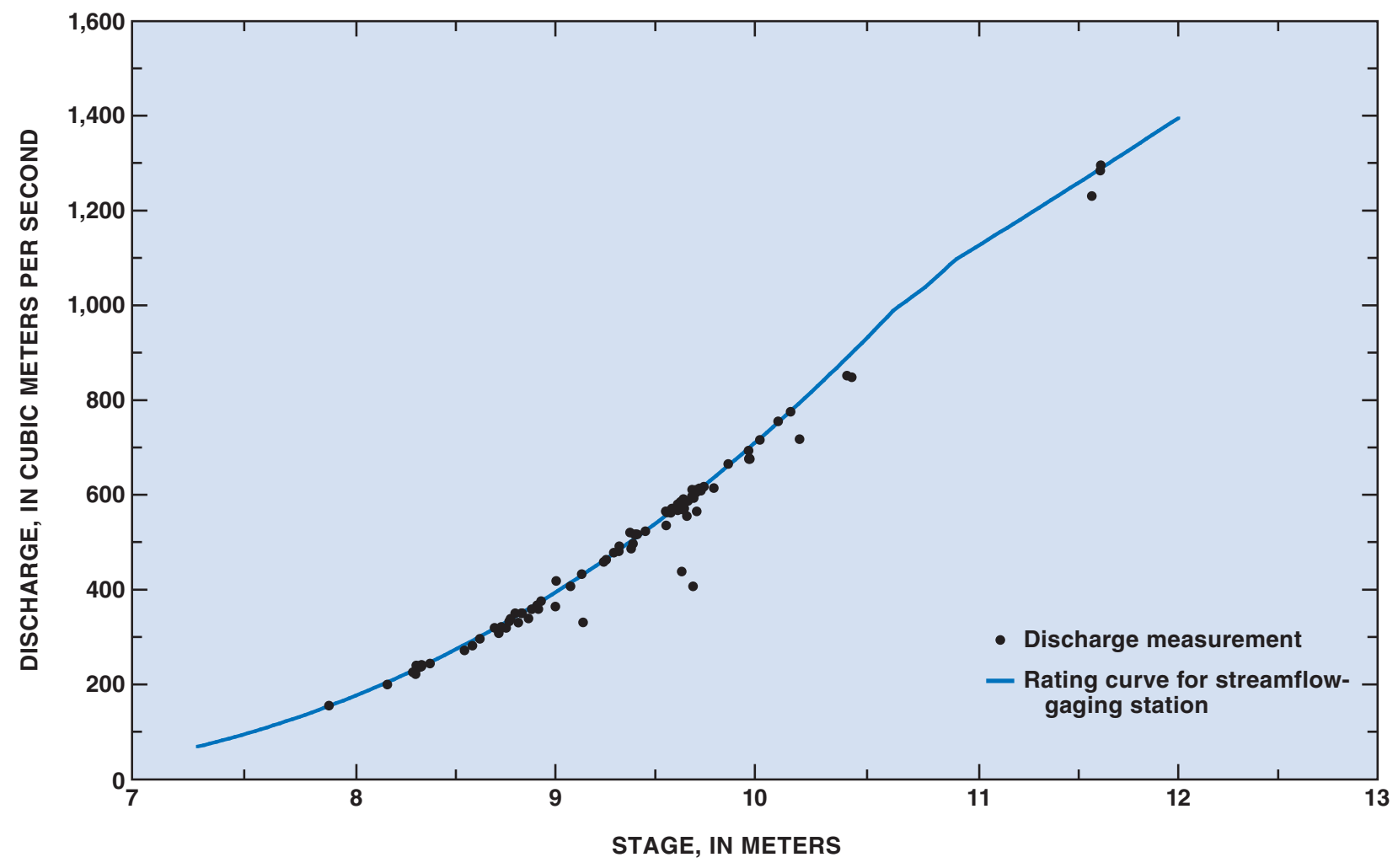

Figure 6. Rating curve formulated for the Colorado River above the Little Colorado River streamflow-gaging station and discharge measurements used in the formulation of the rating curve. Note the lack of measurements between 800 and 1,200 cubic meters per second. Opportunities for discharge measurements in this discharge range are rare. 


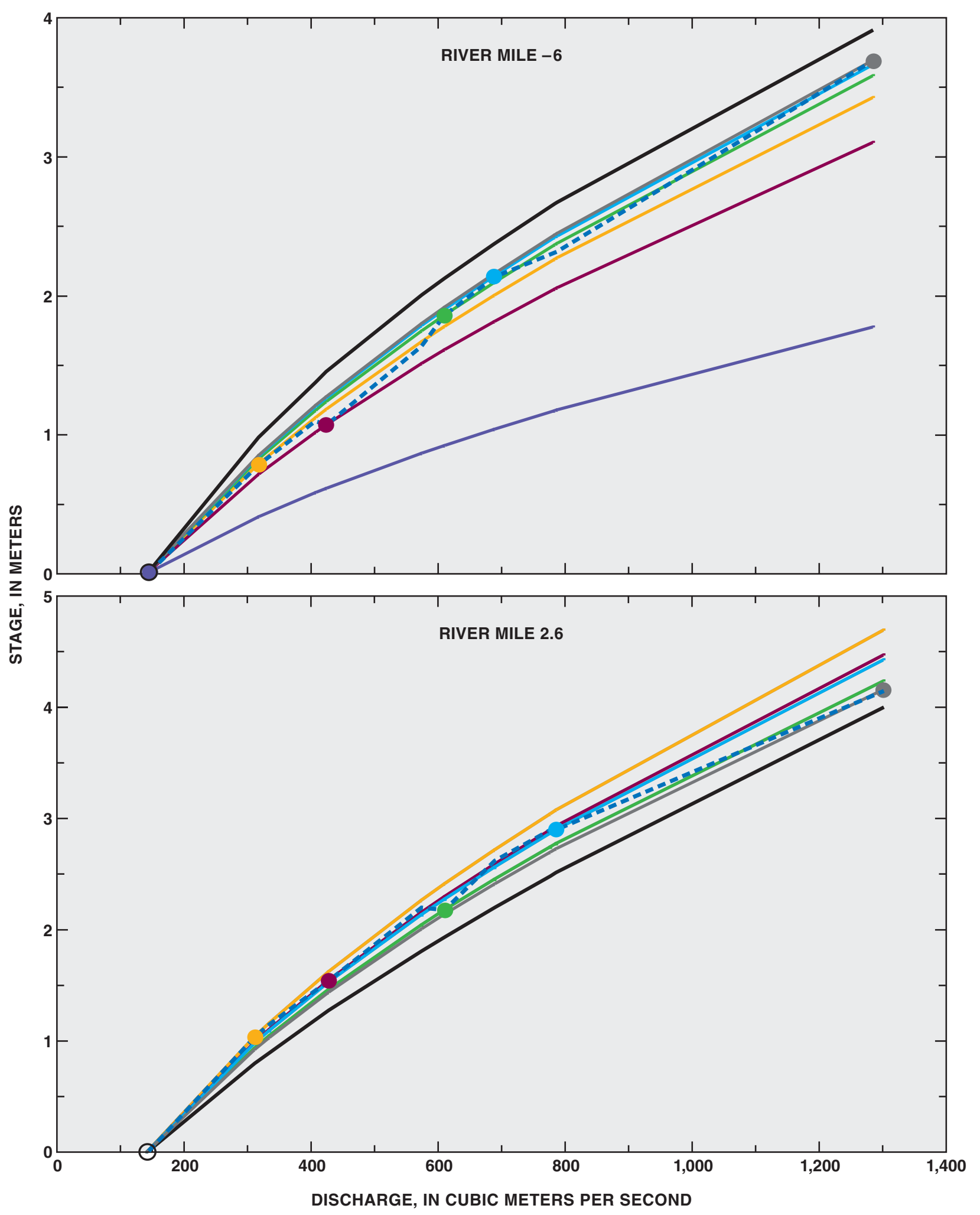

Figure 7. Comparisons of the Northern Arizona University (NAU) stage measurements at known discharges with Stream Tube model for Alluvial River Simulation (STARS) predictions and rating curves constructed with the stage-normalized curve (SNC). The lower discharge value used in the SNC method is the same in each case and is represented by the open circle. The upper discharge value used in the SNC method is shown with a solid colored circle. The color of the upper circle is the same as the line showing the corresponding stage-discharge relation. The accuracy of the SNC-derived rating curves improves as the difference between stagedischarge pairs increases. 


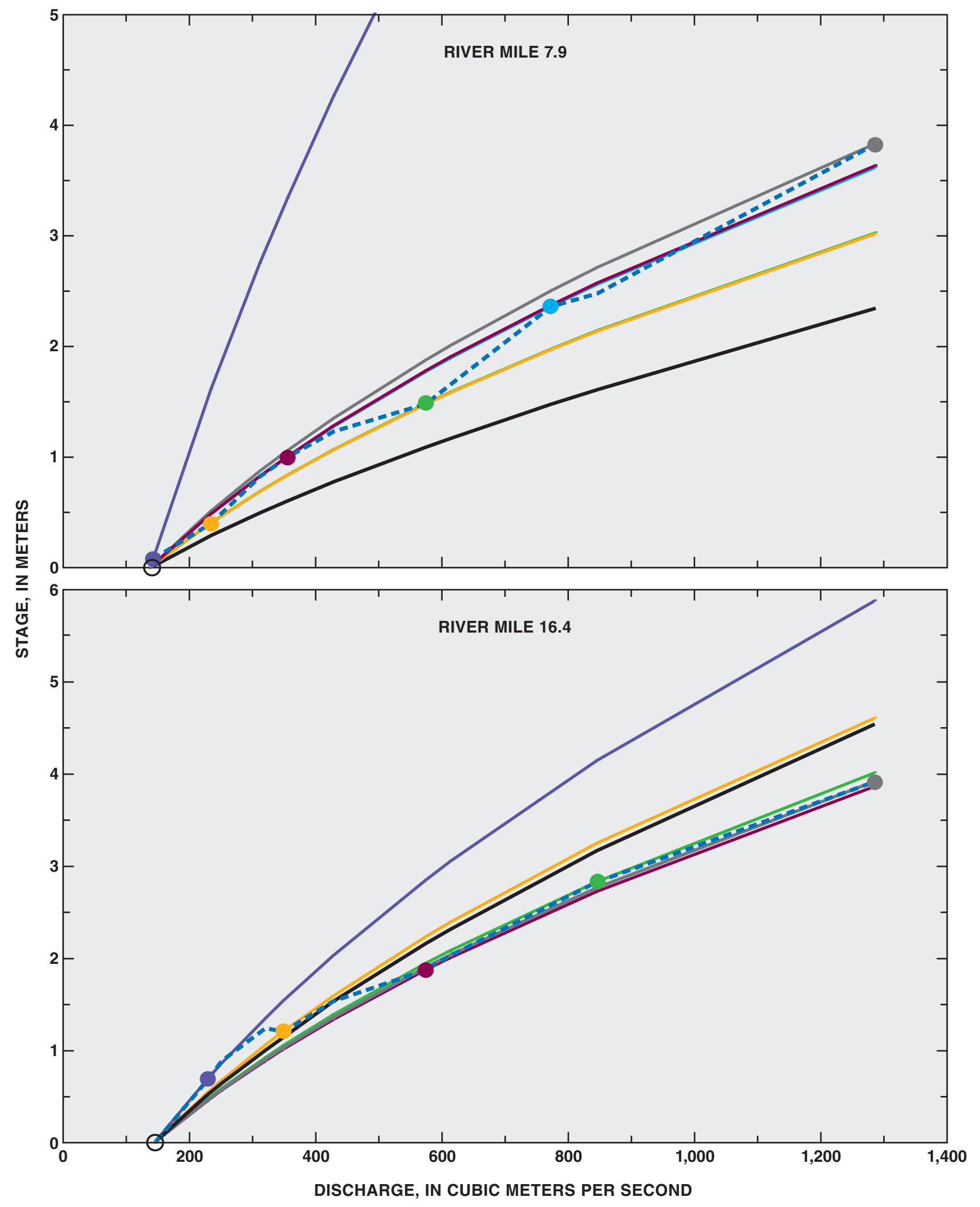

Figure 7. Continued. 


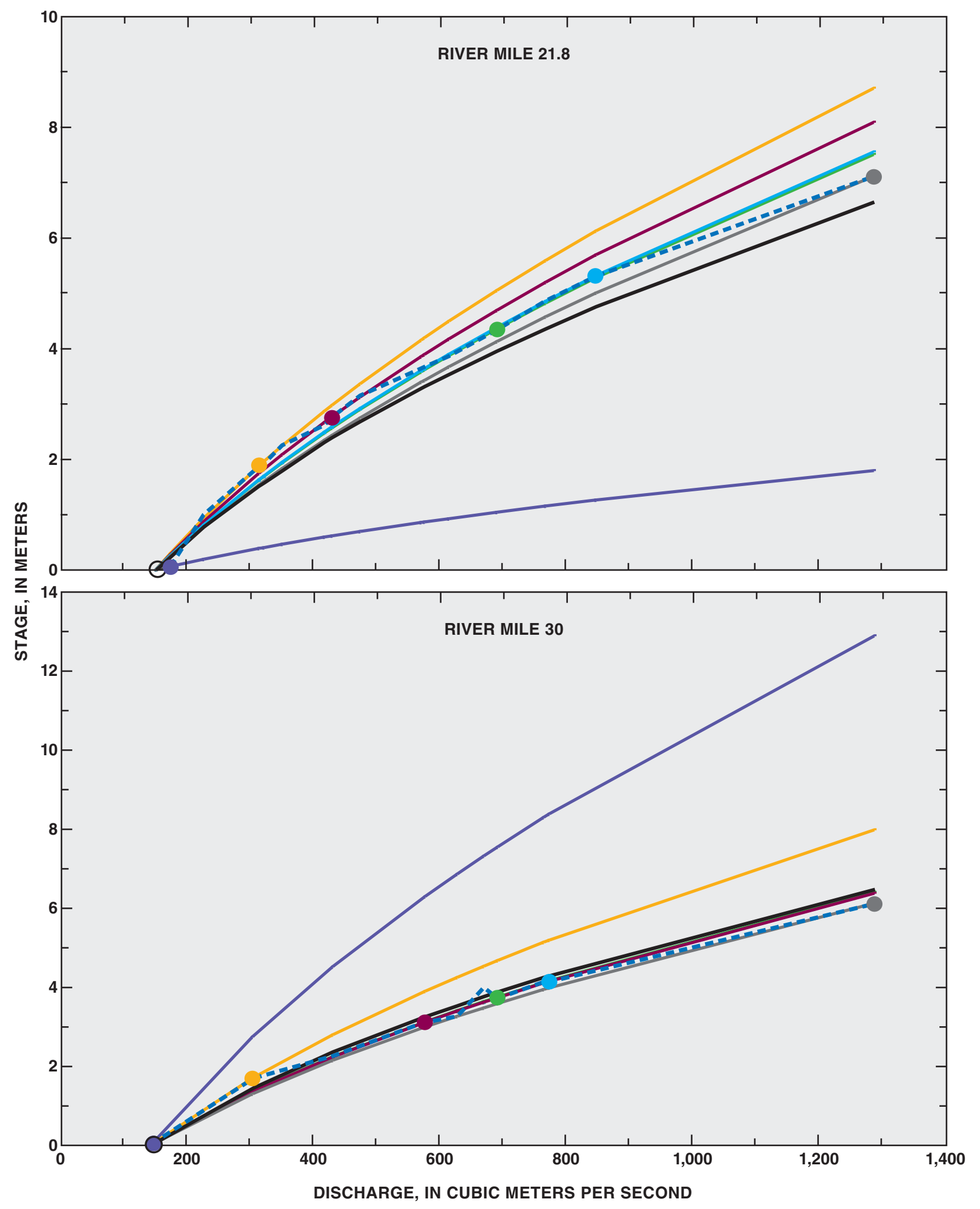

Figure 7. Continued. 


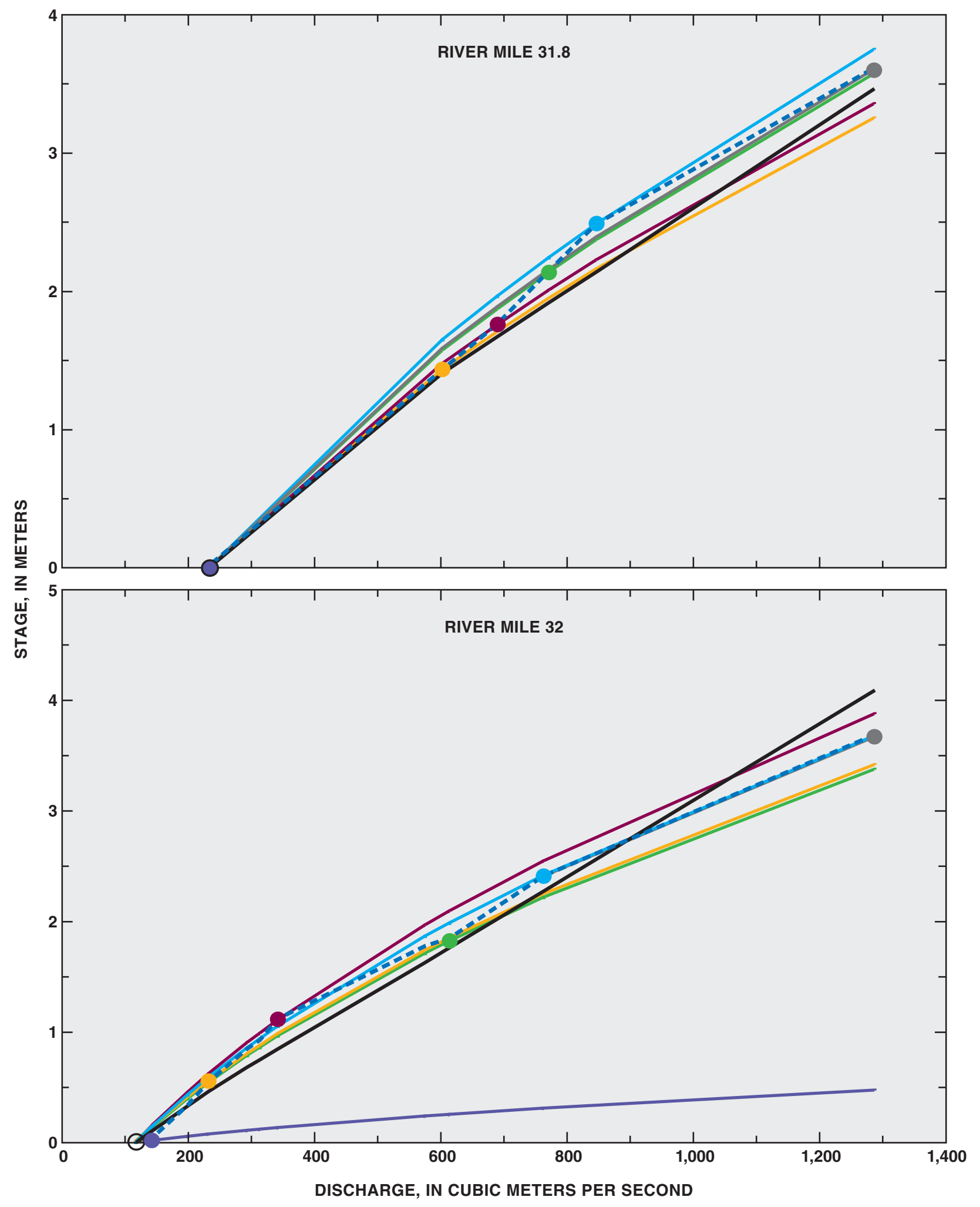

Figure 7. Continued. 


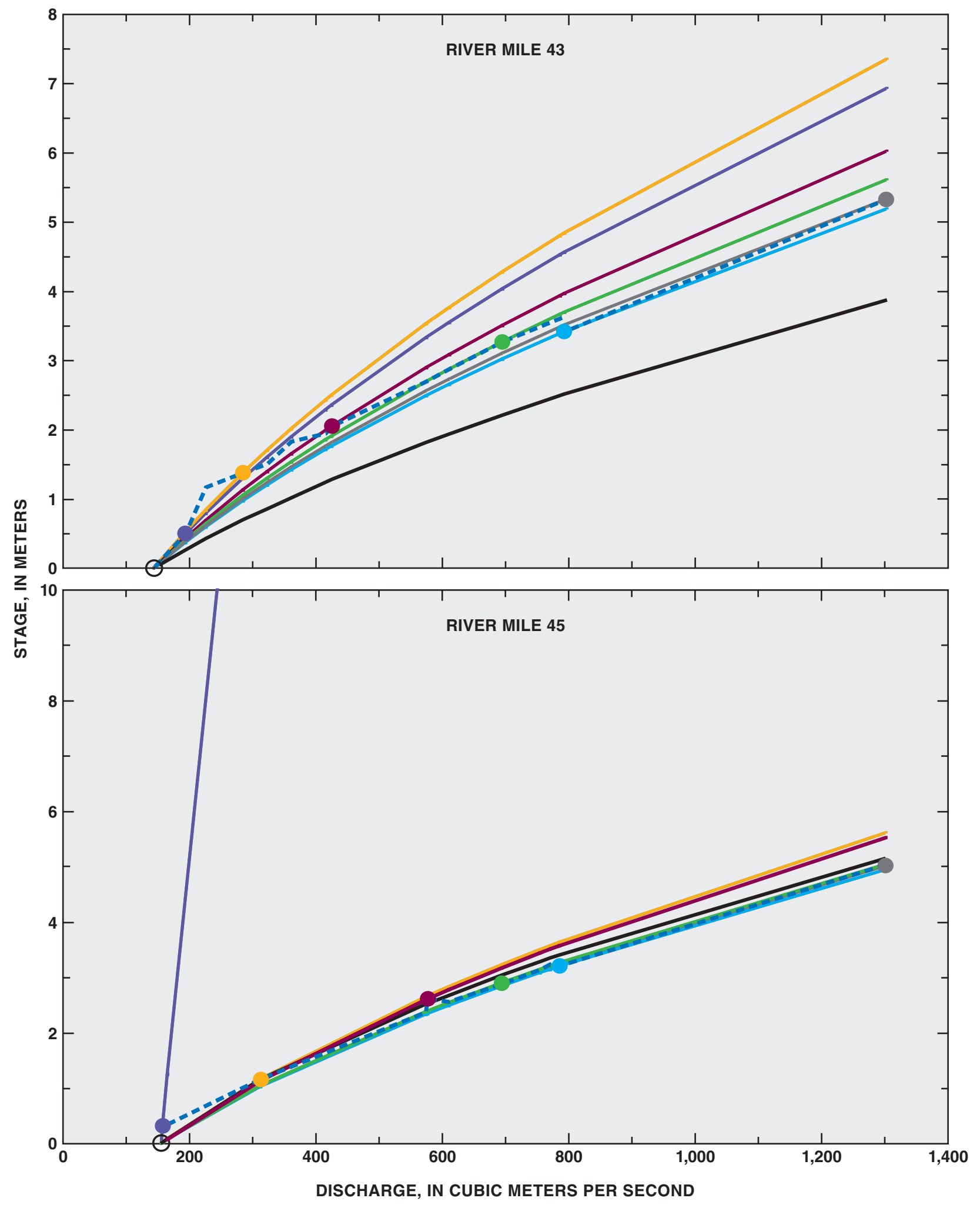

Figure 7. Continued. 


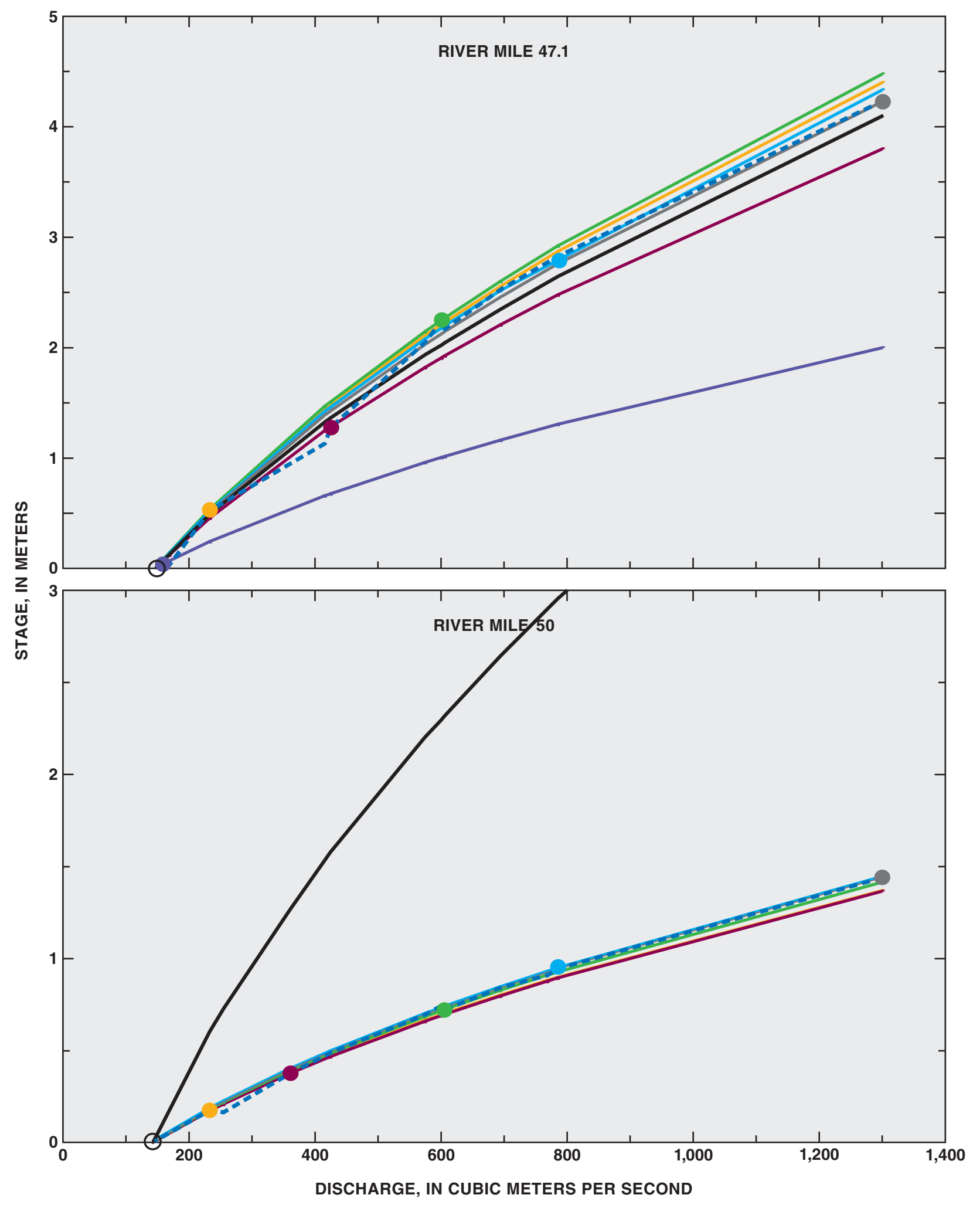

Figure 7. Continued. 


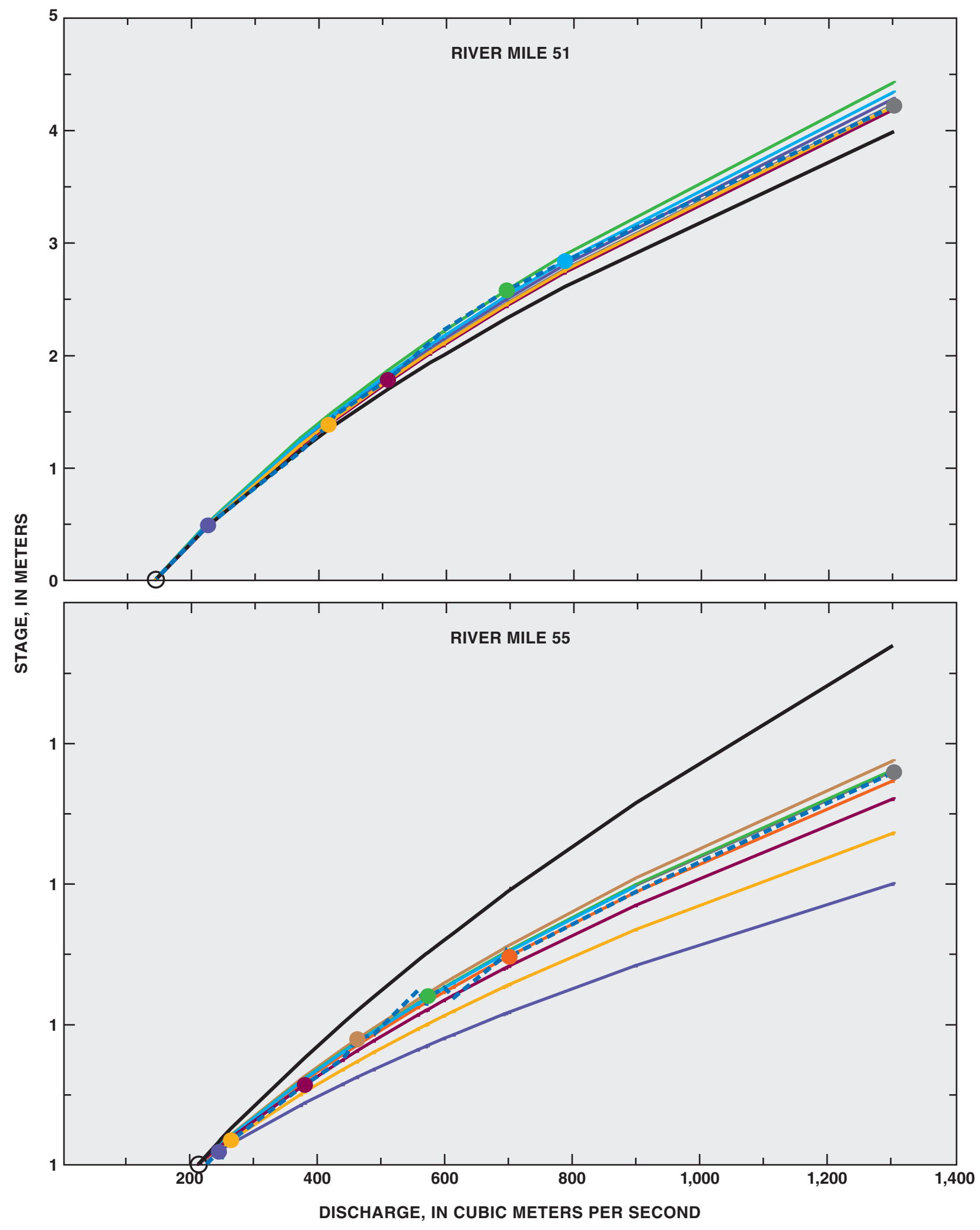

Figure 7. Continued. 

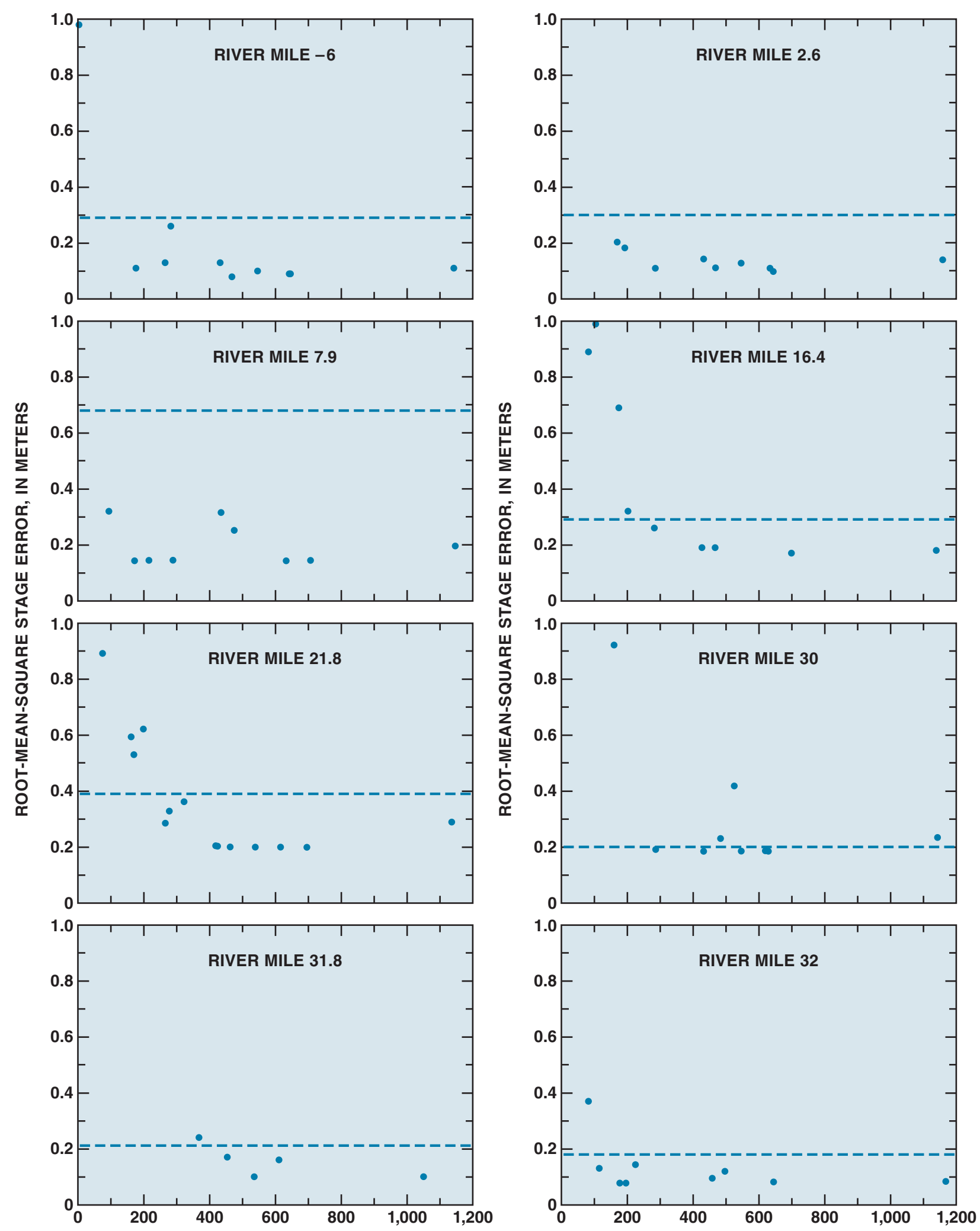

DIFFERENCE IN DISCHARGE USED IN STAGE-NORMALIZED METHOD, IN CUBIC METERS PER SECOND

Figure 8. Root-mean-square (RMS) error of the stage predicted by the stage-normalized curve (SNC) method and by the Stream Tube model for Alluvial River Simulation (STARS) model. RMS error in the predictions of stage with the SNC method generally declines as the difference between the stage-discharge pairs used in the method increases. Both methods are compared to the Northern Arizona University stage-discharge data. 

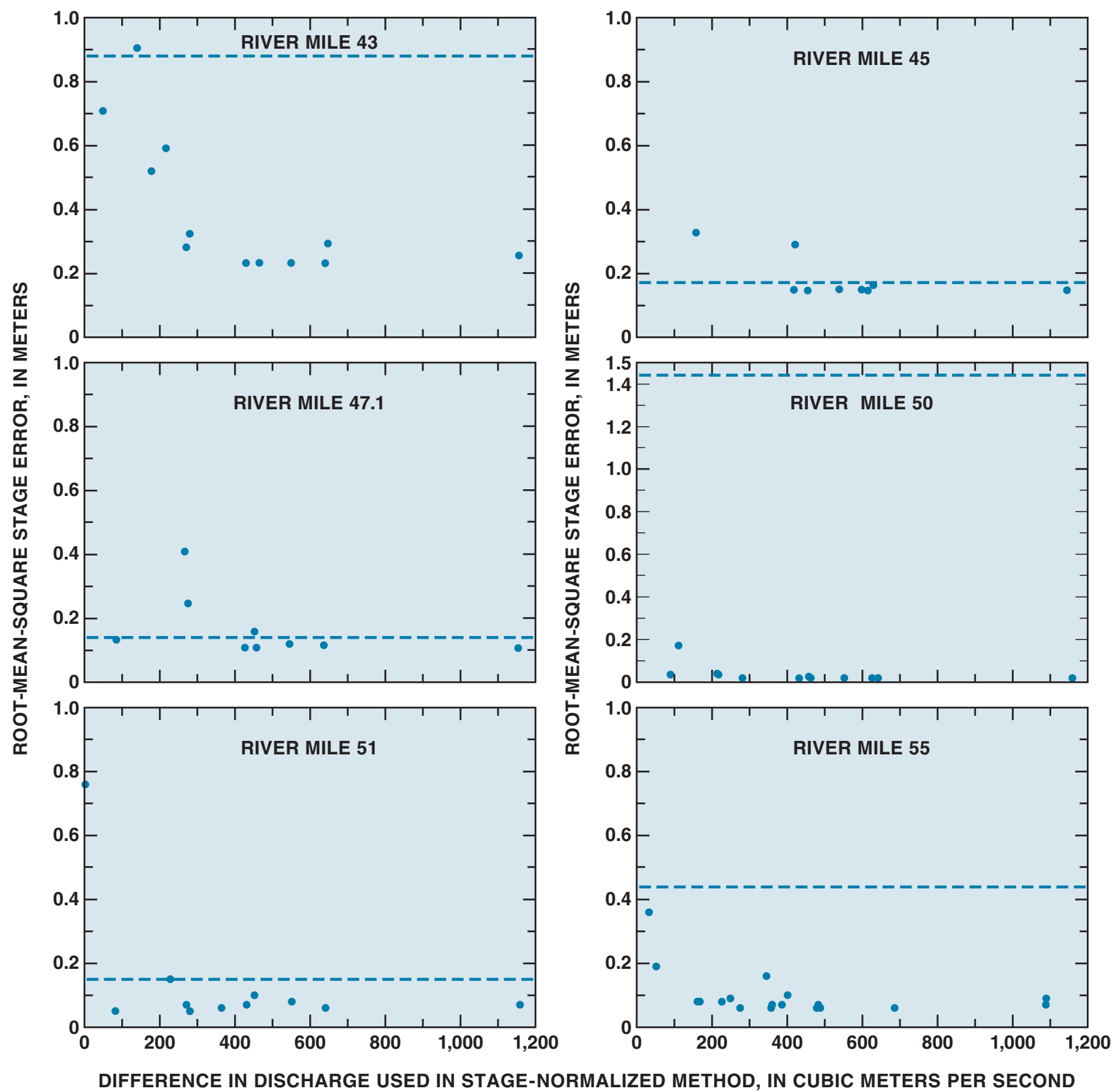

DIFFERENCE IN DISCHARGE USED IN STAGE-NORMALIZED METHOD, IN CUBIC METERS PER SECOND

EXPLANATION

- Stage-normalized curve - - STARS model method

Figure 8. Continued. 


\section{CONCLUSION}

The accuracy of the SNC method depends on the degree to which the local stage-discharge relations are similar to the reach-averaged values. In most of the test cases, the reach-averaged values represented well the local stage-discharge relations if the difference between the stage-discharge pairs is sufficiently large. The accuracy of the SNC method also depends on the accuracy of the input data. In figure 8 , for example, the errors in the predicted rating curves do not always decline smoothly as the difference between the stagedischarge pairs increases. This is likely a result of small discharge errors in the NAU stage-discharge values that are used as input into the SNC method.

The test results show that in most cases, the STARS model will produce usefully accurate predictions. The STARS model is convenient to use because it is entirely predictive in that no additional information is required to produce a stage prediction at a given location. The SNC method is entirely empirical and requires a pair of measured stages at known discharges; accuracy increases with increasing difference between the stages. With sufficient difference between the discharges used to formulate a rating curve with the SNC method, it appears to offer an improvement in accuracy over the STARS model. Data required for the SNC method are easily obtained in the field. The construction of maps showing the elevation of river stages at 226 and $1,273 \mathrm{~m}^{3} / \mathrm{s}$, as proposed by the Information Technology Section of the GCMRC (Mike Liszewski and Steve Mietz, Grand Canyon Monitoring and Reasearch Center, Information Technology Resources, oral commun., 2002) would provide the input data required for the application of the SNC method.

\section{REFERENCES}

Gauger, R.W., 1997, River-stage data, Colorado River, Glen Canyon Dam to upper Lake Mead, Arizona, 1990-94: U.S. Geological Survey Open-File Report 96-626, $20 \mathrm{p}$.

Graf, J.B., 1995, Measured and predicted velocity and longitudinal dispersion at steady and unsteady flow, Colorado River, Glen Canyon Dam to Lake Mead: American Water Resources Association Bulletin, April 1995, v. 31, no. 2, p. 265-281.
Griffin, E.R., and Wiele, S.M., 1997, Refined calculation of hydraulic geometry in the Colorado River through Grand Canyon: Eos, v. 78, n. 46, p. 288.

Keulegan, G.H., 1938, Laws of turbulent flows in open channels, Res. Paper RP1151: National Bureau of Standards, 21, p. 707-41.

Korman, J., Wiele, S.M., Randle, T., Melis, T.S., and Topping, D., 2000, User's guide to the graphic interface combining flow, stage, sediment-input models developed for the Colorado River in Grand Canyon, prepared for the Grand Canyon Monitoring and Research Center, Flagstaff, Arizona, 18 p.

Randle, T.J., and Pemberton, E.L., 1987, Results and analysis of STARS modeling efforts of the Colorado River in Grand Canyon: Glen Canyon Environmental Studies Report, 41 p.

Rantz, S.E., and others, 1982a, Measurement and computation of streamflow: Volume 1, measurement of stage and discharge: Geological Survey Water Supply Paper 2175, v. 1, p. 1-284.

Rantz, S.E., and others, 1982b, Measurement and computation of streamflow: Volume 2, computation of discharge, Geological Survey Water Supply Paper 2175, v. 2, p. 285-631.

Schmidt, J.C., and Graf, J.B., 1990, Aggradation and degradation of alluvial sand deposits, 1965 to 1986, Colorado River, Grand Canyon National Park, Arizona: U.S. Geological Survey Professional Paper 1493, 74 p.

Stevens, L.E., 1990, The Colorado River in Grand Canyon, a guide: Flagstaff, Arizona, Red Lake Books, 115 p.

U.S. Department of the Interior, 1995, Operation of Glen Canyon Dam: Final environmental impact statement, Colorado River Storage Project, Coconino County, Arizona: Salt Lake City, Utah, USA, 337 p.

Wiele, S.M., and Griffin, E.R., 1997, Modifications to a one-dimensional model of unsteady flow in the Colorado River through the Grand Canyon, Arizona: U.S. Geological Survey Water Resources Investigation Report 97-4046, 17 p.

Wiele, S.M., and Smith, J.D., 1996, A reach-averaged model of diurnal discharge wave propagation down the Colorado River through the Grand Canyon: Water Resources Research, v. 32, no. 5, p. 1375-1386.

Wilson, R.T., 1986, Sonar patterns of Colorado River bed, Grand Canyon: Las Vegas, Nevada, Proceedings of the Fourth Federal Interagency Sedimentation Conference, v. 2 , p. 5-133 to 5-142. 